\title{
FORMULASI TIWUL DAN BERAS INSTAN TINGGI PROTEIN MENGGUNAKAN TEPUNG UBI KAYU-TEPUNG LEMBAGA JAGUNG DENGAN PENAMBAHAN KONSENTRAT PROTEIN KEDELAI
}

\author{
Instant and Rice Tiwul Formulation Rich in Protein Using Cassava-Corn germs \\ Flours With Soy Protein Concentrate Addition
}

\author{
Friska Citra Agustia ${ }^{1}$ dan Herastuti Sri Rukmini ${ }^{2}$ \\ ${ }^{1}$ Prodi Ilmu Gizi, Fakultas Ilmu-Ilmu Kesehatan, Universitas Jenderal Soedirman \\ ${ }^{2}$ Prodi Ilmu dan Teknologi Pangan, Fakultas Pertanian, Universitas Jenderal Soedirman
}

furissuka@yahoo.co.id

\begin{abstract}
The objective of the present study was to improve the tiwul quality especially its protein content by formulating instant tiwul using corn germs flours and soy protein concentrate. We conducted a factorial randomized trial. The treatment factors consisted of product shape (instant tiwul dan instant rice), proportion of cassava - corn germ flour $(100: 0,90: 10,80: 20,70: 30)$ and presentation of soy protein concentrate $10 \%, 10 \%, 20 \%$ dan $30 \%)$.The result showed that instant tiwul made of cassava flour-corn germ flour of 70:30 w/w and soy protein of $3 \% \mathrm{w} / \mathrm{w}$ was higher in protein and fat content than that of instant tiwul made of cassava flour without substitution of corn germ flour and without supplementation of soy protein, i.e. $6.06 \%$ and 1.14\%, respectively for protein content and $1.66 \%$ and $0.39 \%$, respectively for fat content. Besides the shape of product (tiwul and instant rice) not affected protein and fat content. Their coefficient rehydration were high, ranged $2-4 . \quad$ In general, their sensory characteristics of cooked instant tiwul were good (rather chewy texture, and good in flavor, aroma, and color).
\end{abstract}

Keywords: Cassava flour, corn germ flour, instant tiwul, soy protein concentrate

\begin{abstract}
ABSTRAK
Tiwul adalah makanan tradisional (agak kenyal, makanan seperti nasi yang dibuat dari tepung ubi kayu) mengandung protein yang rendah dan biasanya memiliki karakteristik fisik yang rendah. Tujuan penelitian adalah meningkatkan kualitas tiwul terutama kandungan proteinnya dengan formulasi tiwul instan menggunakan tepung lembaga jagung dan konsentrat protein kedelai. Penelitian menggunakan rancangan acak kelompok dengan 3 faktor yaitu bentuk produk (tiwul instan dan beras instan), proporsi tepung ubi kayu dan tepung lembaga jagung $(100: 0,90: 10,80: 20,70: 30)$ dan persentase konsentrat protein kedelai $(0 \%, 10 \%, 20 \%$ dan 30\%). Hasil menunjukkan tiwul instan yang terbuat dari tepung ubi kayu-tepung lembaga jagung 70:30 b/b dan konsentrat protein kedelai 3\% mengandung protein dan lemak lebih tinggi dari tiwul yang terbuat dari tepung ubi kayu tanpa substitusi tepung lembaga jagung dan tanpa suplementasi konsentrat protein kedelai yaitu $6,06 \%$ dan $1,14 \%$, berturut-turut untuk kandungan protein dan $1.66 \%$ dan $0.39 \%$, berturut-turut untuk kadar lemak. Sedangkan bentuk produk tiwul (tiwul maupun beras instan) tidak mempengaruhi kadar protein dan kadar lemaknya. Tiwul memiliki koefisien rehidrasi cukup tinggi, berkisar $2-4$. Secara umum, tiwul instan memiliki karakteristik sensori yang baik (tekstur agak kenyal, dan flavor, aroma, dan warna yang baik).
\end{abstract}

Kata kunci : tiwul instan, tepung ubi kayu, tepung lembaga jagung, konsentrat protein kedelai 


\section{PENDAHULUAN}

Tiwul tradisional dibuat dengan cara sederhana oleh sebagian masyarakat di daerah Kabupaten Wonogiri (Jawa Tengah) dari gaplek (ubi kayu yang dikeringkan) kemudian dibuat tepung. Tepung ditambah sedikit air, garam, dan mungkin gula, kemudian diuleni (dicampur homogen) dan dibentuk granula (butir-butir kecil seperti butir pasir kasar) dengan cara menggulunggulung adonan di atas maupun dengan tangan. Granula adonan selanjutnya dikukus selama kurang lebih 30 menit. Hasil pengukusan (tiwul) biasanya dimakan dengan kelapa parut. Warna dan cita rasa tiwul ini sangat ditentukan oleh kualitas gaplek sebagai bahan dasar. Gaplek dari jenis ubi kayu varietas tertentu atau gaplek yang tidak baik kualitasnya akan menghasilkan tiwul yang agak pahit dan warna coklat gelap dengan bau yang tidak enak (apek) dan nilai gizi rendah.

Kelemahan proses tradisional dan produknya akan diatasi melalui proses pembuatan tiwul instan dari ubi kayu yang dipreparasi terlebih dahulu sebelum dikeringkan dan dibuat tepung. Untuk meningkatkan nilai gizi, terutama protein, tepung ubi kayu yang dihasilkan perlu disubstitusi dengan tepung bahan pangan lain yang proteinnya relatif tinggi yang pada penelitian ini dipilih tepung lembaga jagung serta disuplementasi dengan konsentrat protein kedelai.

Pada dasarnya pembuatan tiwul dan beras instan bertumpu pada proses gelatinisasi pati dengan adanya air dalam adonan campuran tepung tepung dan panas pada saat pengukusan (steam blanching). Setelah dikukus, tiwul yang diperoleh dikeringkan sehingga diperoleh tiwul instan kering yang tahan simpan dan siap tanak dalam waktu pendek (sekitar 10 menit). Tiwul instan kering dengan mudah menyerap air yang ditambahkan dan akan mengembang kembali pada saat pengukusan.

Ubi kayu sebagai bahan dasar mempunyai kadar protein rendah. Ubi kayu mempunyai kadar protein 0.8-1.0 $\%$, lemak 0.2-0.5 \%, karbohidrat $32.0 \%$, abu $0.3-0.5 \%$, serat $0.8 \%$, air $65 \%$, dengan kandungan energi $127 \mathrm{kkal}$ per 100g bahan (Grace 1997). Bahan dasar yang digunakan untuk membuat tepung substitusi adalah lembaga jagung (corn germ), yang masing-masing menempati proporsi berat $13 \%$ dan $3 \%$ terhadap berat total biji jagung. Lembaga ini kaya akan protein yaitu $26.5 \%$ (lembaga jagung), selain tinggi protein, lembaga 
tersebut juga tinggi lemak. Lembaga jagung mengandung lemak $35 \%$ (Kent 1975). Selain tinggi protein dan lemak, lembaga serealia umumnya kaya akan mineral. Lembaga jagung, menurut Nielsen et al. (1979), mengandung lemak sekitar $35 \%$, protein $19 \%$, dan mineral $10 \%$ (berbasis berat kering).

Peningkatan kandungan protein produk selain dengan lembaga jagung diatas juga dengan suplementasi konsentrat protein kedelai dalam jumlah relatif kecil 1-3\%. Di pasaran konsentrat tersebut memiliki kadar protein berkisar $70-73 \%$.

Teknologi pembuatan tiwul dan beras instan dari tepung bahan dasar dan tepung substitusi diawali dengan pembuatan atau preparasi masing-masing tepung yang digunakan dalam proses pengolahan. Preparasi dilakukan terhadap lembaga jagung. Preparasi dilakukan dengan melakukan steam blanching menggunakan larutan basa panas yakni larutan soda kue $1.5 \%$ pada suhu sekitar $90^{\circ} \mathrm{C}$ selama 10-15 menit. Setelah itu lembaga tersebut dikeringkan sampai kering patah (oven; $50-55^{\circ} \mathrm{C}$ ), dihaluskan dan diayak 60 mesh. Preparasi perlu dilakukan agar tepung lembaga bebas dari bau dan flavor yang tidak dikehendaki (pahit, langu, (beauny flavor; opak). Senyawa-senyawa offflavor dapat diakibatkan oleh aktivitas enzim lipoksigenase pada lemak (Nielsen et al. 1977, Theerakulkait et al. 1995), adanya senyawa-senyawa peptida hidrofobik maupun senyawa-senyawa pahit alami yang ada pada lembaga maupun dedak dan pollard (bekatul). Senyawa-senyawa pahit ini dapat dikurangi atau dihilangkan dengan penggunaan larutan basa panas (Lindsay 1996 dalam Fennema 1996).

Produk pangan berkualitas tinggi hanya dapat dihasilkan dari bahan dasar yang baik kualitasnya, preparasi bahan yang baik, teknologi proses yang baik pula dan sesuai dengan tujuan hasil akhir, serta penggunaan bahan-bahan tambahan yang sesuai dengan tujuan proses dan aman bagi kesehatan. Tujuan penelitian ini adalah memperoleh teknologi formulasi tiwul instan siap tanak dengan kadar protein relatif tinggi, koefisien rehidrasi tinggi dan sifat-sifat sensori yang baik.

\section{METODE}

\section{Tempat dan waktu}

Penelitian dilakukan di Laboratorium Teknologi Pengolahan Jurusan Teknologi Pertanian UNSOED. Penelitian dilaksanakan pada Bulan April hingga Oktober 2012. 


\section{Bahan dan Alat}

Bahan utama adalah ubi kayu yang dipesan khusus dari pasar wage Purwokerto, fraksi lembaga jagung (corngerm) dari SMK Temanggung; bahan aditif pangan (soda kue, bubuk agar, vanillin), garam, gula pasir; berbagai bahan kimia untuk analisis kimia sesuai prosedur yang digunakan. Alat utama yang digunakan adalah neraca analitik, oven elektrik, blender, ayakan stainless steel 60 mesh dan 80 mesh, cetakan granular, alat masak skala rumah tangga; dan berbagai alat gelas untuk analisis.

\section{Rancangan Penelitian}

Penelitian berbentuk eksperimen faktorial menggunakan Rancangan Acak Kelompok (RAK). Faktor perlakuan terdiri atas; Bentuk Produk (T) :T1 = Tiwul Instan, T2 = Beras Instan; Proporsi tepung ubi kayu - tepung substitusi (tepung lembaga jagung) $(\mathrm{P} ; \mathrm{b} / \mathrm{b}): \mathrm{P} 0=$ $100: 0, \mathrm{P} 1=90: 10, \mathrm{P} 2=80: 20, \mathrm{P} 3=$ 70 : 30; Suplementasi konsentrat protein kedelai (\% b/b terhadap total tepung) : $\mathrm{K} 0=0 \%, \mathrm{~K} 1=1 \%, \mathrm{~K} 2=2 \%, \mathrm{~K} 3=3 \%$. Dari ketiga faktor diperoleh percobaan faktorial $4 \times 4 \times 2=32$ Tiap percobaan diulang 2 kali.

\section{Tahapan Penelitian}

Pembuatan tepung ubi kayu, tepung lembaga jagung,dan tiwul instan (Gambar 1,2,3)

\section{Analisis Produk dan Analisis Data}

Analisis produk terhadap kadar air (metode oven), kadar abu (metode gravimetri), protein (metode mikrokjedahl), lemak (metode soxhlet) dan karbohidrat by difference (Soedarmadji et al.1984) dan Uji sensori (Soekarto 1985). Analisis terhadap aroma, tekstur, warna, flavor, dilakukan secara sensori dengan metode uji skoring yang ditentukan berdasarkan intensitasnya dan nilai kesukaan dengan uji hedonik. Penilaian sensori dilakukan oleh 15 panelis semi terlatih (mahasiswa). Data dianalisis menggunakan analisis of variance atau analisis ragam atau uji Fischer (uji F) pada taraf $95 \%$ dan apabila ada pengaruh nyata dilanjutkan dengan Duncan's Multiple Range Test (DMRT) pada taraf $5 \%$. 
J.Gipas, November 2017, Volume 1 Nomor 1

ISSN 2599-0152 eISSN 2599-2465

http://jos.unsoed.ac.id/index.php/jgps
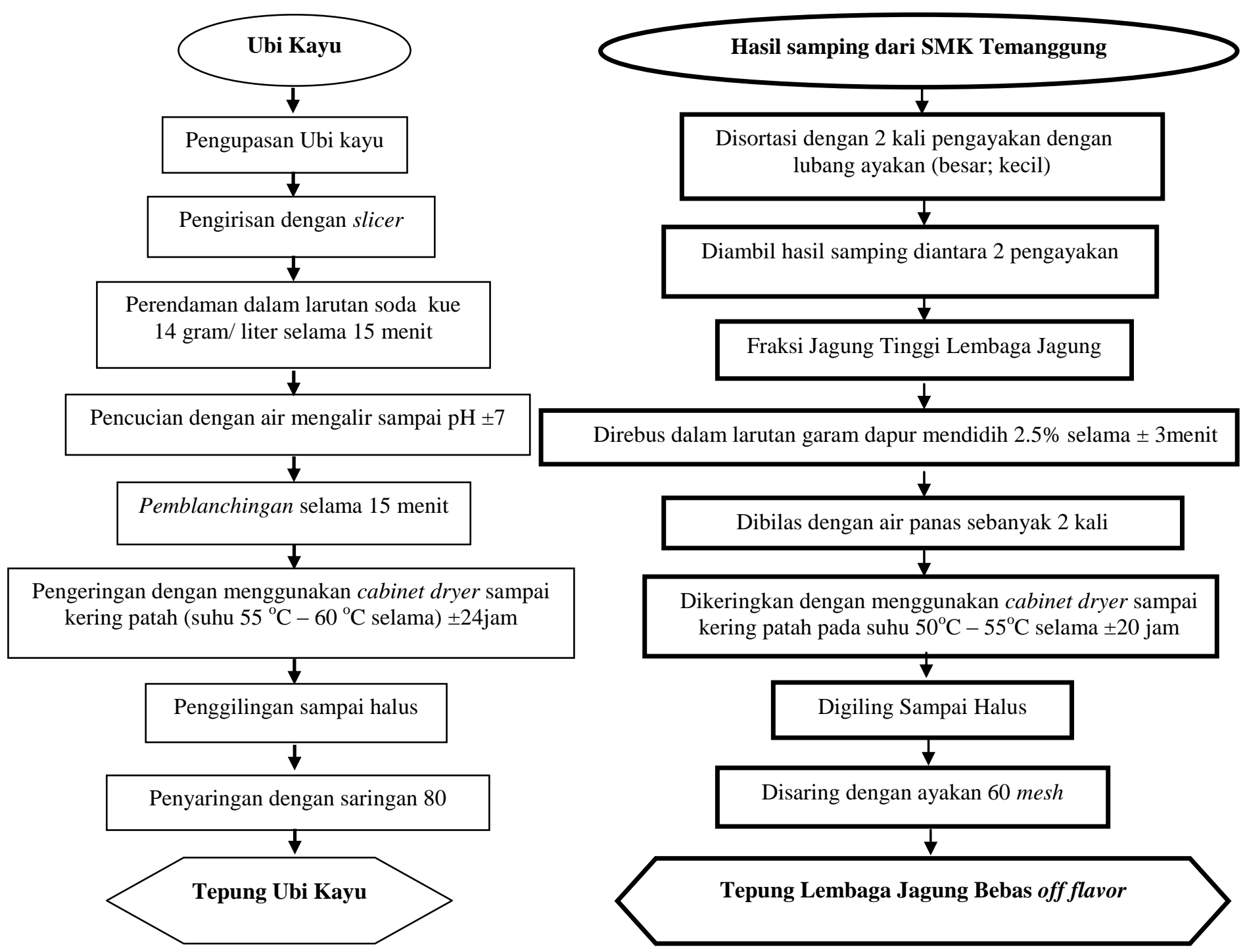

Fraksi Jagung Tinggi Lembaga Jagung

Direbus dalam larutan garam dapur mendidih $2.5 \%$ selama \pm 3 menit

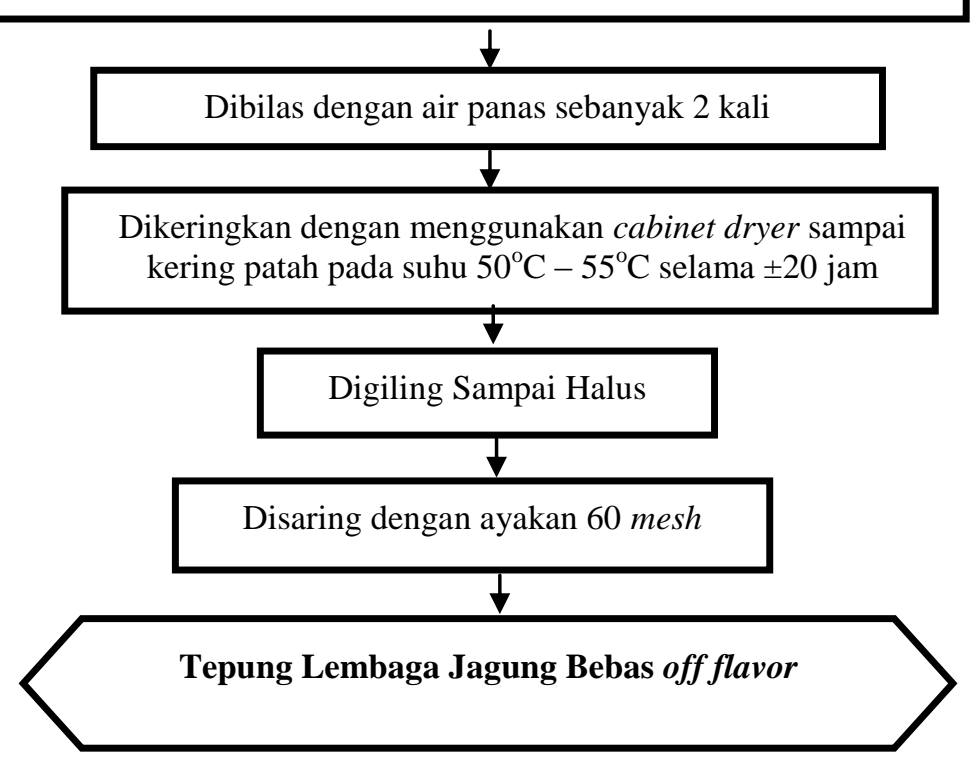

Gambar 1. Pembuatan tepung ubi kayu

Gambar 2. Pembuatan Tepung Lembaga jagung 


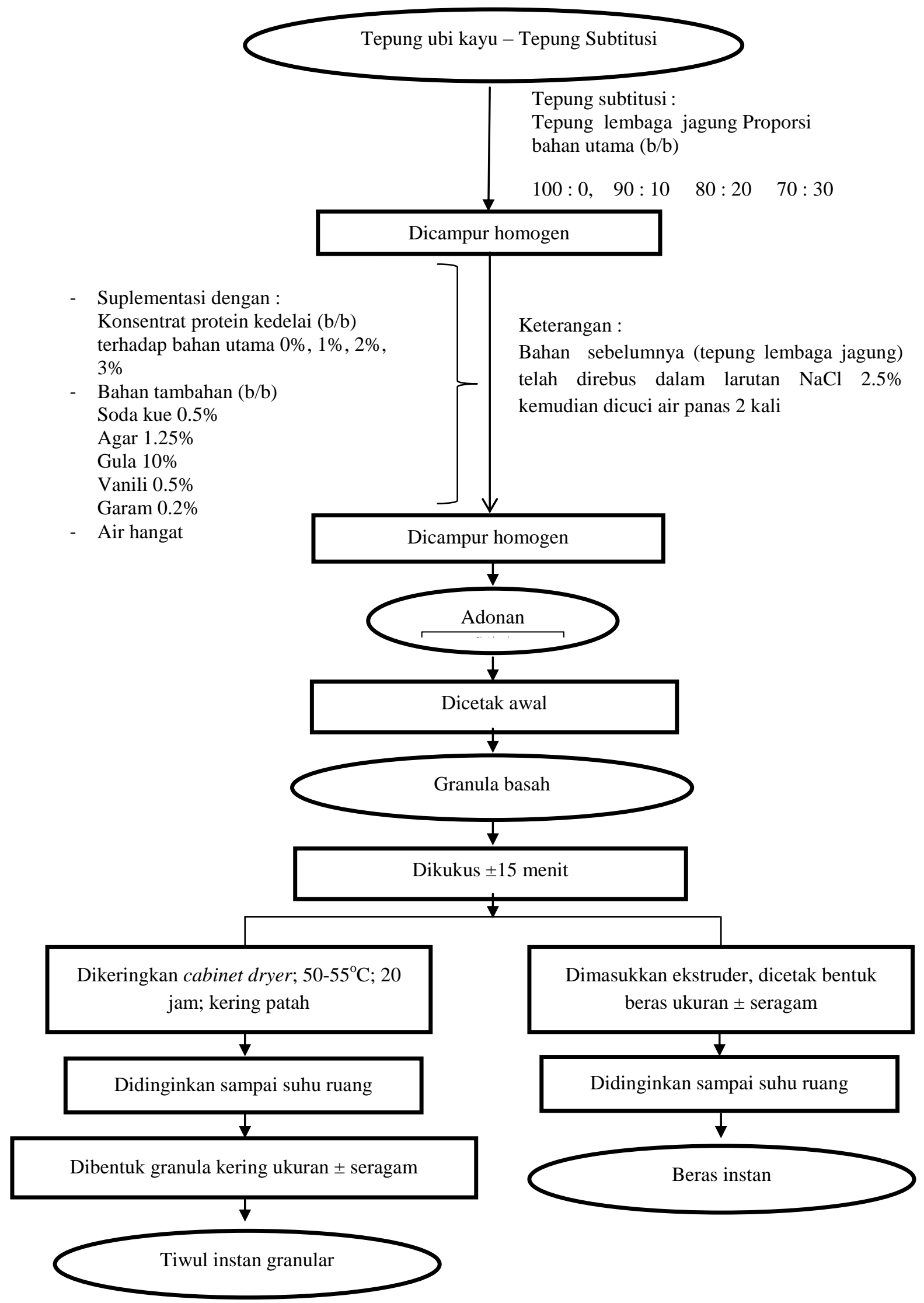

Gambar 3. Formula Tiwul Instan 


\section{HASIL DAN PEMBAHASAN}

Tujuan utama penelitian adalah menghasilkan tiwul instan kering siap tanak (ready to cook dried instant tiwul) dengan daya rehidrasi tinggi, kadar protein tinggi dan produk tanak dengan citarasa enak, aroma enak dan relatif kenyal. Tujuan tersebut dapat dicapai dengan memperhatikan perlakuan yang diterapkan pada bahan dasar (ubi kayu) dan bahan substitusi (lembaga jagung), menetapkan persentase optimal dari bahan-bahan tambahan pangan yang digunakan pada proses pembuatan tiwul instan (soda kue, agar, gula, garam, vanili), menetapkan persentase protein kedelai yang optimal untuk menghasilkan tiwul dengan kadar protein relatif tinggi.

\section{Tepung Ubi Kayu Dan Tepung Substitusi}

\section{a. Tepung ubi Kayu}

Pada pembuatan tepung ubi kayu (Gambar 1), ubi kayu irisan direndam dalam larutan soda kue $\mathrm{pH} 9$ terutama untuk memberikan sifat porous kepada produk (tepung ubi kayu) agar sifat rehidrasi tiwul instan yang dibuat dengan menggunakan tepung ubi kayu ini sebagai tepung utama relatif tinggi. Rendemen ubi kayu iris kering terhadap ubi kayu segar rata-rata $33.70 \%$, sedangkan rendemen tepung ubi kayu 80 mesh sebesar $10.45 \%$ terhadap ubi kayu segar.

Hasil analisis kimia terhadap tepung ubi kayu 80 mesh yang dihasilkan sebagai berikut: kadar air $8.10 \%$, total mineral (abu) $1.24 \%$, lemak kasar $0.56 \%$, protein total $2.21 \%$. Tepung ubi kayu berwarna putih bersih dan berasa tawar.

\section{b. Tepung substitusi}

Tepung substitusi yang digunakan pada pembuatan tiwul instan adalah tepung lembaga jagung. Percobaan awal terhadap penggunaan kedua tepung ini menunjukkan adanya off-flavor agak pahit pada tiwul yang dihasilkan. Percobaan menghilangkan off-flavor tersebut dengan steam blanching menggunakan panas yang mengandung soda kue (air $\mathrm{pH} \pm 9$ ) tidak berhasil menghilangkan rasa tersebut.

Untuk menghasilkan tiwul instan sesuai tujuan maka perlu perbaikan perlakuan terhadap lembaga jagung. Oleh karena itu dicoba perlakuan lain yakni merebus lembaga dalam larutan garam dapur $2.5 \%$ mendidih 3 menit, kemudian dicuci dengan air panas tiga kali sehingga diperoleh lembaga relatif bebas garam. Perlakuan dengan $\mathrm{NaCl}$ meniadakan rasa agak pahit pada tepung lembaga jagung.

Dilakukan pengujian terhadap kadar proksimat tepung substitusi yang 
digunakan pada pembuatan tiwul instan. Analisis kadar proksimat (kadar air, kadar abu, kadar lemak total dan kadar Protein) lembaga jagung dan tepung lembaga jagung dapat dilihat pada Tabel 1.

Dari data pada Tabel 1 dapat dilihat bahwa kadar protein pada tepung lembaga jagung sangat tinggi yaitu mencapai $13.94 \%$ sehingga tepung ini sangat tepat digunakan sebagai tepung substitusi yang kaya akan protein pada pembuatan tiwul instan dan beras instan.

Tabel 1. Komposisi Kimia Bahan Dasar Tiwul Instan

\begin{tabular}{ccccc}
\hline Bahan & Kadar Air (\%) & Kadar Abu $(\%)$ & Lemak $(\%)$ & Protein $(\%)$ \\
\hline Lembaga Jagung & 13.72 & 2.59 & 6.39 & 11.44 \\
Tepung Lembaga Jagung & 7.03 & 3.53 & 15.18 & 13.94 \\
\hline
\end{tabular}

\section{Tiwul Instan (Granular) Tepung}

\section{Lembaga Jagung}

\section{a. Kadar Air Dan Kadar Abu}

Data hasil analisis kadar air dan kadar abu tiwul instan dengan tepung lembaga jagung (Tabel 2) menunjukkan bahwa perlakuan proporsi tepung ubi kayu-tepung lembaga jagung dan suplementasi konsentrat protein kedelai relatif tidak berpengaruh terhadap keduanya.

Kadar air tiwul instan berkisar antara $4.95 \%$ - $5.89 \%$. Kisaran yang sempit ini disebabkan karena kadar air tiwul lebih diakibatkan oleh lama pengeringan tiwul basah menjadi tiwul kering patah yang relatif lama (sekitar 20 jam, suhu $50^{\circ} \mathrm{C}$, cabinet dryer). Kisaran kadar air yang rendah tersebut menjamin masa simpan tiwul instan yang tinggi.
Tabel 2. menunjukkan kadar abu (kadar total mineral) berkisar dari $1.34 \%$ - $3.19 \%$ bk. Kadar abu tiwul instan diberikan oleh kandungan mineral dari tepung ubi kayu (1.24 \% lembaga jagung (3.53\% bk.) dan dari potein kedelai yang digunakan. Kadar abu tiwul instan yang diperoleh relatif rendah. 
Tabel 2. Kadar Air Dan Kadar Abu Tiwul Instan Dengan Lembaga Jagung

\begin{tabular}{ccc}
\hline Bahan & Kadar air $(\%)$ & Kadar abu $(\%$ bk $)$ \\
\hline T1P0K0 & 5.44 & 1.35 \\
T1P0K1 & 5.46 & 1.34 \\
T1P0K2 & 5.17 & 1.39 \\
T1P0K3 & 5.67 & 1.38 \\
T1P1K0 & 5.45 & 1.64 \\
T1P1K1 & 4.95 & 1.62 \\
T1P1K2 & 5.78 & 1.51 \\
T1P1K3 & 5.89 & 1.76 \\
T1P2K0 & 5.81 & 2.29 \\
T1P2K1 & 5.55 & 2.20 \\
T1P2K2 & 5.26 & 2.27 \\
T1P2K3 & 5.82 & 2.12 \\
T1P3K0 & 5.75 & 3.19 \\
T1P3K1 & 5.45 & 2.70 \\
T1P3K2 & 5.43 & 2.68 \\
T1P3K3 & 5.69 & 2.91 \\
\hline
\end{tabular}

\section{Keterangan :}

T1 : tiwul instan, P0 : substitusi 0\%, P1 : substitusi 10\%, P2 : substitusi 20\%, P3 : substitusi $30 \%$, K0 : suplementasi $0 \%, \mathrm{~K} 1$ : suplementasi $1 \%$, K2 : suplementasi $2 \%$, $\mathrm{K} 3$ : suplementasi $3 \%$

\section{b. Kadar Protein Dan Kadar Lemak}

Analisis kadar protein dan lemak dilakukan terhadap tiwul instan dengan substitusi tepung lembaga jagung tertinggi yakni 70:30 b/b dan kontrol yakni tepung ubi kayu 100\%, masing-masing dengan suplementasi protein kedelai $0 \%, 1 \%, 2 \%$, $3 \%$.
Tanpa Substitusi

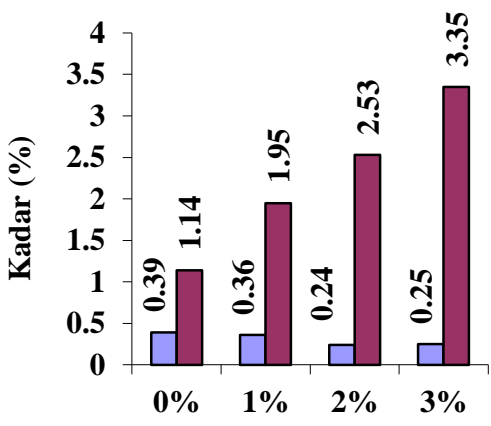

Dengan Substitusi

$\square$ Lemak (bk)

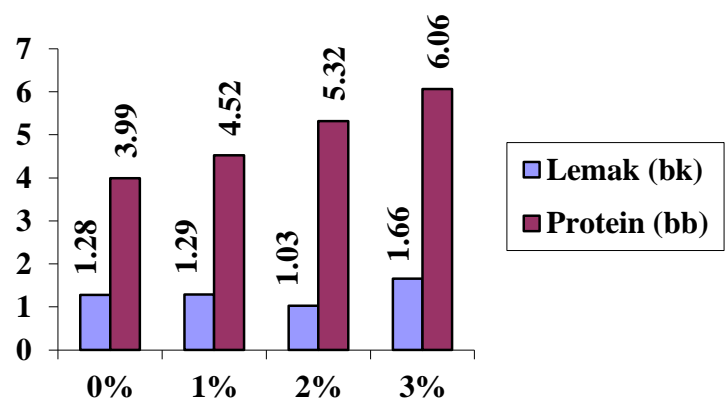

Suplementasi Protein kedelai

Gambar 4. Kadar Protein Dan Lemak Tiwul Instan Kontrol Dan Subtitusi Dengan Tepung Lembaga Jagung 70:30 b/b Pada Suplementasi Protein Kedelai Yang Berbeda. 
Hasil analisis terhadap tiwul kontrol dan tiwul substitusi tepung lembaga jagung $30 \%$ atau $70: 30 \mathrm{~b} / \mathrm{b}$ pada kisaran kadar air tiwul relatif seragam $(4.95-5.89 \%)$ dapat dilihat pada Gambar 4. Tiwul instan dari tepung ubi kayu 100 $\%$ tanpa penambahan protein kedelai mengandung protein $1.14 \%$ dan lemak $0.39 \%$ bk. Pada suplementasi protein kedelai $3 \%$, tiwul kontrol mengandung protein $3.35 \%$ dan lemak $0.25 \%$ bk. Dari sini diketahui bahwa tanpa penggunaan tepung substitusi sulit menghasilkan tiwul instan dengan kadar protein mendekati kadar protein beras.

Substitusi tepung ubi kayu dengan tepung lembaga jagung 70:30 tanpa suplementasi protein kedelai menghasilkan tiwul instan dengan kadar protein $3.99 \%$ dan lemak $1.28 \%$ bk. Dengan semakin tingginya suplementasi dengan protein kedelai, kadar protein tiwul instan meningkat. Pada suplementasi $3 \%$ tiwul instan memiliki kadar protein mendekati kadar protein beras yakni mencapai $5.81 \%$

Dari kenyataan tersebut di atas diketahui bahwa untuk menghasilkan tiwul instan dengan tepung lembaga jagung yang mempunyai kadar protein mendekati protein beras diperlukan suplementasi dengan protein kedelai $3 \%$. Pada proporsi tepung ubi kayu : tepung lembaga jagung
70:30 b/b tiwul instan yang dihasilkan memiliki komposisi kimia sebagai berikut : kadar protein $6.06 \%$, kadar lemak 1.66 $\%$ bk, kadar air $5.69 \%$, kadar abu $2.91 \%$ bk. dan kadar karbohidrat (by difference) sekitar $85 \%$.

\section{c. Sifat Fisikokimia Tiwul Instan}

Sifat fisikokimia pada prinsipnya adalah sifat-sifat yang terkait dengan penggunaan bahan antara lain densitas kamba, rehidrasi, kelarutan, viskositas, sifat emulsi, sifat berbuih dan sifat reologis. Pada penelitian ini dikaji tentang koefisien rehidrasi dan densitas kamba. Diluar sifat fisikokimia tetapi dimasukkan ke dalam sub bab ini adalah rendemen tiwul instan. Besarnya rendemen, koefisien rehidrasi dan densitas kamba dari tiwul instan yang menggunakan tepung lembaga jagung dan tiwul instan kontrol (tanpa tepung substitusi) disajikan pada Tabel 3.

\section{Rendemen Tiwul Instan}

Tabel 3 menunjukkan bahwa rendemen tiwul instan berkisar dari $102 \%$ sampai $112 \%$. Perlakuan penelitian tidak berpengaruh nyata terhadap rendemen tiwul. Nilai rendemen tiap kombinasi perlakuan yang lebih besar dari $100 \%$ diakibatkan oleh penggunaa 
Tabel 3. Rendemen, koefisien rehidrasi dan densitas kamba tiwul instan dengan tepung lembaga jagung

\begin{tabular}{cccc}
\hline Bahan & Rendemen $(\%)$ & Koefisien rehidrasi & Densitas kamba(g/ml $)$ \\
\hline T1P0K0 & 108.02 & 2.99 & 0.47 \\
T1P0K1 & 109.71 & 3.61 & 0.42 \\
T1P0K2 & 109.89 & 3.93 & 0.41 \\
T1P0K3 & 109.78 & 3.71 & 0.40 \\
T1P1K0 & 102.84 & 3.78 & 0.41 \\
T1P1K1 & 103.76 & 3.52 & 0.41 \\
T1P1K2 & 107.43 & 3.86 & 0.39 \\
T1P1K3 & 112.20 & 3.39 & 0.40 \\
T1P2K0 & 106.04 & 2.66 & 0.42 \\
T1P2K1 & 107.47 & 2.97 & 0.41 \\
T1P2K2 & 2.91 & 0.41 \\
T1P2K3 & 107.86 & 3.21 & 0.42 \\
T1P3K0 & 105.17 & 2.67 & 0.43 \\
T1P3K1 & 105.79 & 2.98 & 0.45 \\
T1P3K2 & 104.34 & 3.04 & 0.42 \\
T1P3K3 & 104.15 & 2.70 & 0.43 \\
\hline
\end{tabular}

Keterangan :

108.39

T1 : Tiwul Instan (Granular), P0 : substitusi 0\%, P1 : substitusi 10\%, P2 : substitusi 20\%, P3 : substitusi 30\%, K0 : suplementasi $0 \%, \mathrm{~K} 1$ : suplementasi $1 \%, \mathrm{~K} 2$ : suplementasi $2 \%, \mathrm{~K} 3$ : suplementasi $3 \%$

\section{Koefisien Rehidrasi Tiwul Instan}

Koefisien rehidrasi menunjukkan tingginya daya rehidrasi atau pengikatan air tiwul instan saat dimasak. Koefisien rehidrasi yang tinggi berarti tiwul instan mudah mengikat air, sehingga saat pemasakan dengan uap air atau saat dicampur dengan air tekstur mudah lunak atau teksturnya mudah lunak sehingga mudah dikunyah.

Dari penelitian ini koefisien rehidrasi tiwul instan berkisar dari 2 sampai 4. Tiwul instan tanpa substitusi dan tanpa suplementasi memiliki koefisien rehidrasi paling rendah yakni 2.9. Hal ini diakibatkan oleh tidak adanya tambahan gugus-gugus yang bersifat hidrofilik yang berasal dari tepung lembaga jagung maupun dari protein kedelai terutama yang berasal dari protein. tiwul dari unit kombinasi yang menggunakan tepung substitusi dan atau dengan tepung suplementasi mempunyai koefisien rehidrasi lebih tinggi berkisar 3- 4 . Kisaran nilai koefisien rehidrasi $3-4$ termasuk tinggi yang artinya tiwul instan mudah lunak saat dimasak atau waktu pemasakan pendek karena memiliki daya rehidrasi tinggi.

Daya rehidrasi tiwul instan kecuali diberikan oleh tepung ubi kayu, tepung lembaga jagung dan protein kedelai yakni dari senyawa-senyawa yang mudah mengikat air yang terkandung di dalamnya 
terutama protein dan pati. Selain itu juga diakibatkan oleh bubuk agar yang diberikan dalam jumlah relatif tinggi $(1.75 \%)$. Agar merupakan salah satu produk ekstraksi seaweeds yang tergolong hidrokoloid yang mudah mengikat air (Glicksman 1986).

\section{Densitas Kamba Tiwul Instan}

Densitas kamba menggambarkan berapa besar volume kemasan yang diperlukan untuk setiap satuan berat badan. Densitas kamba yang rendah menunjukkan bahwa bahan bersifat bulky atau volumenya tinggi untuk setiap satuan berat, yang hal ini tidak menguntungkan dari aspek transportasi bahan tersebut. Tabel 3 menunjukkan bahwa perlakuan tidak berpengaruh nyata pada besarnya densitas kamba tiwul instan. Densitas kamba tiwul instan berkisar antara 0.39 0.47 .

\section{Sifat Sensori Tiwul Instan}

Tampilan tiwul instan kering dari semua perlakuan dari aspek bentuk cukup bagus. Bentuk granular dengan diameter sekitar 1.5 - $2.0 \mathrm{~mm}$ dengan warna terang putih kecoklatan.

Tiwul tanak (Gambar 5) memiliki kekenyalan atau kepulenan bagus sesuai dengan koefisien rehidrasi yang tinggi. Aroma tiwul tanak sedikit agak apak khas aroma jagung meskipun sudah digunakan vanillin jumlah besar (0.7 \%) sebagai penutup cita rasa (flavor) khas jagung yang tidak disuka. Namun demikian cita rasa jagung umumnya mudah disamarkan dengan penggunaan penambah cita rasa yang lebih tepat seperti esens cita rasa cokelat, mocca atau caramel atau ditambah bahan penunjang seperti bubuk cokelat atau bubuk susu (whole milk powder).

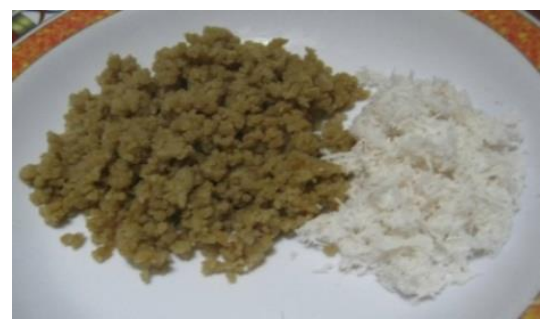

Gambar 5. Tiwul Tanah

Rasa pahit yang diakibatkan oleh aktivitas enzim lipoksigenase pada minyak lembaga jagung yang terdapat dalam jumlah relatif tinggi, seperti yang dikemukakan oleh
Gardner dan Inglett (1991) dan Theerakulkait et al. (1995) sudah tidak terdeteksi lagi pada tiwul tanak. Seperti telah disebutkan dimuka perlakuan 
perendaman dalam larutan garam dapur $2.5 \%$ mendidih selama 3 menit pada lembaga jagung atau tepungnya mampu menghilangkan rasa pahit tersebut. Penggunaan larutan basa (soda kue) seperti yang dikemukakan Lindsay (1996) tidak berhasil menghilangkan rasa pahit lembaga jagung. Cara lain untuk mengatasi rasa pahit lembaga jagung adalah dengan penggunaan tepung lembaga jagung bebas lemak sebagai hasil samping ekstraksi minyak lembaga jagung. Seperti diketahui, lembaga jagung mengandung lemak sekitar $35 \%$ (Blessin et al. 1772, Nielsen et al. 1979). Sifat tanak tiwul instan cukup bagus karena hanya memerlukan rehidrasi dengan air hangat 8 - 10 menit sebelum dikukus. Waktu pengukusan tiwul relatif singkat, hanya perlu waktu 8 - 10 menit.

\section{Beras Instan Dengan Tepung Lembaga Jagung}

\section{a. Kadar Air Dan Kadar Abu}

Kadar air dan kadar abu beras instan dengan substitusi lembaga jagung dilampirkan pada Tabel 4.
Data tiwul ubi kayu $100 \%$ atau kontrol dapat dilihat pada Tabel 2, adapun Tabel 4 menunjukkan bahwa kadar air beras instan dengan substitusi lembaga jagung sedikit lebih tinggi dari kadar air bentuk tiwul instan granular yaitu berkisar 5.43 - 7.36. Perlakuan penelitian tidak berpengaruh signifikan terhadap kadar air, kadar air tiwul relatif sama. Hal ini disebabkan karena kadar air lebih ditentukan oleh lama dan suhu pengeringan tiwul basah menjadi tiwul kering patah (sekitar $20 \mathrm{jam}$; suhu $50^{\circ} \mathrm{C}$; cabinet dryer). Kisaran kadar air yang rendah menjamin masa simpan tiwul instan yang tinggi.

Kadar abu beras instan dengan lembaga jagung berkisar $1.35-3.05 \%$ bk (Tabel 4). Kadar abu beras instan maupun tiwul instan dengan lembaga jagung relatif rendah, adanya perbedaan bentuk granular dan beras tidak berpengaruh terhadap kadar abu. 
Tabel 4. Kadar Air Dan Kadar Abu Beras Instan Dengan Substitusi Lembaga Jagung.

\begin{tabular}{ccc}
\cline { 2 - 3 } Bahan & Kadar air $(\%)$ & Kadar abu (\% bk) \\
\cline { 2 - 3 } T2P0K0 & 5.55 & 1.35 \\
T2P0K1 & 5.61 & 1.37 \\
T2P0K2 & 5.43 & 1.43 \\
T2P0K3 & 5.61 & 1.46 \\
T2P1K0 & 7.36 & 1.87 \\
T2P1K1 & 6.14 & 1.92 \\
T2P1K2 & 6.92 & 2.07 \\
T2P1K3 & 7.20 & 1.92 \\
T2P2K0 & 6.49 & 1.77 \\
T2P2K1 & 6.70 & 1.86 \\
T2P2K2 & 6.66 & 1.90 \\
T2P2K3 & 6.78 & 1.97 \\
T2P3K0 & 6.29 & 3.05 \\
T2P3K1 & 6.63 & 2.81 \\
T2P3K2 & 6.54 & 2.88 \\
T2P3K3 & 7.22 & 2.90 \\
\hline
\end{tabular}

Keterangan :

T2 : beras instan, P0 : substitusi 0\%, P1 : substitusi 10\%, P2 : substitusi 20\%, P3 : substitusi $30 \%, \mathrm{~K} 0$ : suplementasi $0 \%$, K1 : suplementasi 1\%, K2 : suplementasi $2 \%$, K3 : suplementasi $3 \%$

\section{b. Kadar Protein dan Kadar Lemak}

\section{Kadar Protein}

Hasil analisa kadar protein beras instan dengan lembaga jagung pada proporsi tepung ubi kayu-tepung lembaga jagung 70:30 b/b menunjukkan kadar protein beras instan ini hampir sama (berkisar $3.89-5.59 \%$ ) dengan bentuk tiwul instan yang disubstitusi tepung lembaga jagung pada proporsi yang sama (berkisar 3.99 - $6.06 \%$ ), pada penambahan protein kedelai $0-3 \%$.
Apabila kandungan protein beras instan dengan substitusi tepung lembaga jagung 70:30 b/b dibandingkan dengan tiwul tanpa substitusi (100\% tepung ubi kayu), masing-masing ditambah protein kedelai 0, 1, 2 dan $3 \%$ diketahui bahwa bentuk beras instan tidak mempengaruhi kandungan protein produk secara signifikan daripada bentuk tiwul instan karena pada proses pembentukan adonan beras instan hanya berbeda pada saat adonan dicetak dan dimasukkan ke dalam ekstruder kemudian di iris bentuk beras. 


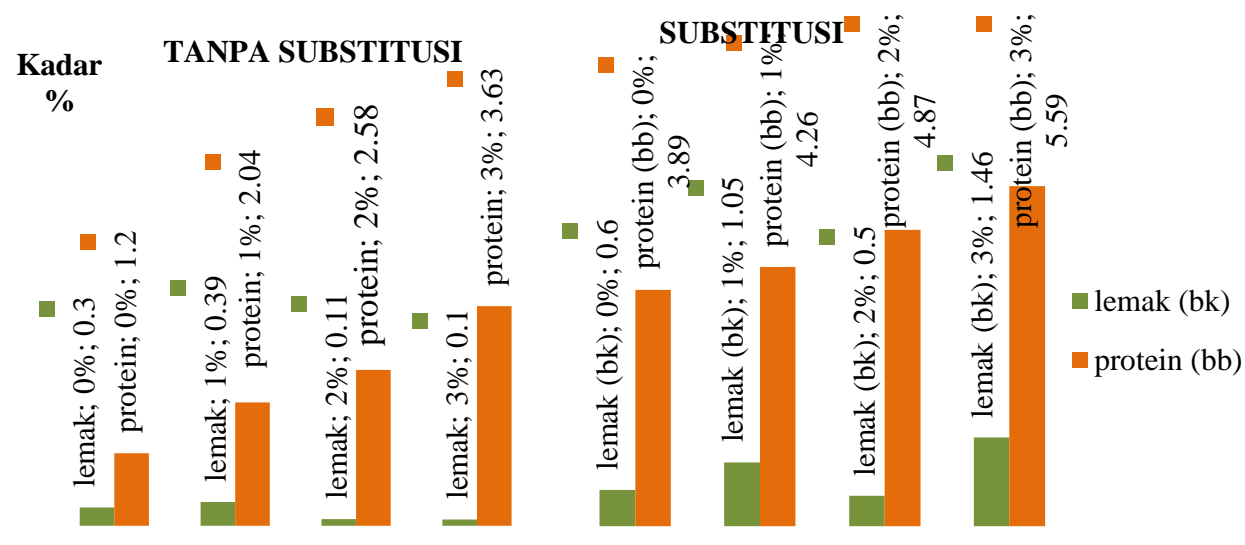

\section{Gambar 6. Kadar Protein Dan Lemak beras Instan Kontrol Dan Subtitusi Dengan Tepung Lembaga Jagung 70:30 b/b Pada Suplementasi Protein Kedelai Yang Berbeda.}

Apabila dibandingkan dengan tiwul instan dari tepung ubi kayu $100 \%$ tanpa suplementasi dengan protein kedelai, beras instan dengan substitusi tepung lembaga jagung $30 \%$ dengan suplementasi protein kedelai 3\% memiliki kandungan protein produk dari $3.2 \%$ menjadi $5.59 \%$, sedangkan tiwul dengan substitusi tepung lembaga jagung 30\% dengan suplementasi yang sama meningkat dari 3.1 menjadi $6.6 \%$.

\section{Kadar lemak}

Hasil analisis kadar lemak beras instan dengan substitusi tepung lembaga jagung 30\% dibandingkan dengan beras dengan tepung ubi kayu 100\% (kontrol), keduanya pada suplementasi protein kedelai $0,1,2$ dan 3\%, disajikan pada Gambar 6. Beras instan dengan substitusi lembaga jagung mengandung lemak berkisar antara $0.6-1.46 \% \mathrm{bk}$, sedangkan tanpa substitusi lembaga jagung $0.3-0.1$
$\%$ bk. Kandungan lemak baik beras instan maupun bentuk tiwul instan sangat rendah. Rendahnya kandungan lemak tiwul menguntungkan dari aspek masa simpan karena tiwul tidak mudah rusak karena oksidasi lemak.

\section{c. Sifat Fisikokimia Beras Instan}

Rendemen, koefisien rehidrasi dan densitas kamba beras instan dengan substitusi tepung lembaga jagung disajikan pada Tabel 5.

\section{Rendemen Beras Instan}

Tabel 5. menunjukkan bahwa rendemen beras instan dengan substitusi lembaga jagung berkisar dari $93 \%$ sampai $118 \%$. Kisaran ini relatif tidak berbeda dengan rendemen bentuk tiwul instan dengan substitusi lembaga jagung (102 $112 \%)$. Perlakuan penelitian tidak berpengaruh nyata terhadap rendemen tiwul baik yang dengan bentuk beras maupun bentuk tiwul instan. 
Tabel 5. Rendemen, Koefisien Rehidrasi Dan Densitas Kamba Beras Instan Dengan Tepung Lembaga Jagung

\begin{tabular}{ccccc}
\hline No & Perlakuan & Rendemen $(\%)$ & Koefisien rehidrasi & Densitas kamba $(\mathrm{g} / \mathrm{ml})$ \\
\hline 1 & T2P0K0 & 93.64 & 3.04 & 0.48 \\
2 & T2P0K1 & 108.70 & 3.03 & 0.46 \\
3 & T2P0K2 & 109.93 & 3.30 & 0.45 \\
4 & T2P0K3 & 112.67 & 2.81 & 0.45 \\
5 & T2P1K0 & 107.77 & 2.67 & 0.44 \\
6 & T2P1K1 & 118.08 & 3.25 & 0.47 \\
7 & T2P1K2 & 102.95 & 3.02 & 0.48 \\
8 & T2P1K3 & 116.98 & 2.51 & 0.46 \\
9 & T2P2K0 & 99.82 & 3.07 & 0.44 \\
10 & T2P2K1 & 106.39 & 2.77 & 0.45 \\
11 & T2P2K2 & 107.80 & 2.39 & 0.49 \\
12 & T2P2K3 & 110.81 & 2.37 & 0.46 \\
13 & T2P3K0 & 106.37 & 2.39 & 0.45 \\
14 & T2P3K1 & 107.16 & 2.14 & 0.46 \\
15 & T2P3K2 & 118.11 & 2.20 & 0.46 \\
16 & T2P3K3 & 112.43 & 2.16 & 0.45 \\
\hline
\end{tabular}

Keterangan :

T2 : beras instan, P0 : substitusi 0\%, P1 : substitusi 10\%, P2 : substitusi 20\%, P3 : substitusi $30 \%, \mathrm{~K} 0$ : suplementasi $0 \%, \mathrm{~K} 1$ : suplementasi $1 \%, \mathrm{~K} 2$ : suplementasi $2 \%, \mathrm{~K} 3$ : suplementasi $3 \%$

\section{Koefisien Rehidrasi Beras Instan}

Tabel 5. menunjukkan bahwa koefisien rehidrasi beras instan berkisar dari 2 sampai 3.5, sedangkan dari Tabel 5 diketahui bahwa koefisien rehidrasi tiwul instan dengan lembaga jagung berkisar dari 2 sampai 4. Dari sini diketahui bahwa koefisien rehidrasi beras instan dengan lembaga jagung berkisar hampir sama dengan bentuk tiwul instan. Kemampuan rehidrasi suatu produk antara lain diakibatkan oleh adanya senyawa-senyawa kimia yang mampu mengikat molekulmolekul air seperti protein dan karbohidrat, sedangkan lemak yang bersifat hidrofobik sulit mengikat air.

\section{Densitas Kamba}

Tabel 5. menunjukkan bahwa densitas kamba beras instan dengan substitusi lembaga jagung berkisar antara $0.44-0.49$. Nilai densitas kamba ini tidak berbeda dengan densitas kamba tiwul instan dengan substitusi lembaga jagung (0.50 - 0.63). Hasil tersebut menunjukkan bahwa perlakuan penelitian tidak berpengaruh nyata terhadap densitas kamba tiwul baik yang berbentuk beras instan maupun tiwul instan granular.

\section{d. Sifat Sensori Beras Instan}

Sifat sensori tiwul instan dan beras instan untuk nilai flavor, kesukaan 
dan aroma hampir sama satu sama lain, bentuk granular dengan diameter $1.5-2.0$ mm dengan waktu rehidrasi relatif sama dan warna terang putih kecoklatan. Sedangkan untuk parameter warna dan tekstur berbeda nyata antara bentuk beras instan dan tiwul instan granular. Beras instan memiliki warna lebih kuning dan tekstur lebih kenyal karena pada saat pencetakan adonan dimasukkan ke dalam ekstruder sehingga adonan lebih merata dan dihasilkan beras instan dengan tekstur yang lebih kenyal karena pori-pori beras menyerap air maksimal saat direhidrasi. Sedangkan untuk tiwul instan warna lebih kecokelatan dan adonan kurang kenyal karena saat pencetakan adonan kurang merata.

Untuk parameter aroma tiwul tanak dari tiwul instan dan beras instan juga masih ada bau khas bahan substitusi tersebut (tepung lembaga jagung) walaupun sudah ditambah vanilin $0.7 \%$ saat pembuatannya. Seperti pada tiwul instan dengan lembaga jagung, pada bentuk beras instan pun dapat diperbaiki aroma dan cita rasanya dengan menggunakan essens lain yang lebih dapat menutup aroma dan cita rasa yang tidak disukai seperti dengan penambahan essens caramel kayu manis, atau mocca saat pembuatannya.

\section{KESIMPULAN}

Kesimpulan penelitian ini menemukan bahwa tepung lembaga jagung sebagai tepung substitusi terhadap ubi kayu, mampu meningkatkan kandungan protein dari tiwul instan tepung ubi kayu (kadar protein $1.14 \%$ ) menjadi $3.35 \%$ untuk tiwul instan pada substitusi $30 \%$ tanpa penambahan konsentrat protein kedelai. Pada tingkat substitusi yang sama namun dengan suplementasi konsentrat protein kedelai $3 \%$ tiwul instan meningkat kandungan proteinnya menjadi $6.06 \%$. Kadar protein beras instan pada proporsi tepung ubi kayu-tepung lembaga jagung 70:30 b/b berkisar $3.89-5.59 \%$ hampir sama dengan bentuk tiwul instan granular pada proporsi tepung ubi kayu-tepung lembaga jagung yang sama berkisar 3.99 $6.06 \%$ pada penambahan protein kedelai 0 - 3\%. Tepung lembaga jagung mampu meningkatkan kandungan protein tiwul instan, namun jenis tiwul yang dihasilkan memiliki kadar lemak rendah berkisar 0.25 $-1.66 \%$ bk sedangkan pada bentuk beras instan berkisar antara $0.6-1.46 \%$ bk. Bentuk beras maupun tiwul instan memiliki kadar protein dan lemak yang tidak berbeda nyata. Tiwul instan dan beras instan memiliki tampilan (bentuk 
granular, warna putih kecokelatan), rendemen dan densitas kamba relatif sama. Koefisien rehidrasi tiwul instan dan beras instan cukup tinggi masing-masing berkisar $2-4$. Tiwul tanak dari beras instan memiliki kekenyalan (kepulenan) lebih baik daripada bentuk tiwul instan granular karena lebih merata saat mengalami proses pencetakan dengan ekstruder. Off-flavor agak pahit dan pahit pada masing-masing tiwul instan dan beras instan disebabkan oleh lembaga jagung relatif dapat ditiadakan dengan preparasi bahan-bahan tersebut dalam larutan garam dapur 3\%, mendidih selama 3 menit. Kedua macam tiwul dan beras instan mempunyai sifat tanak yang baik, pre rehidrasi $8-10$ menit dan pengukusan juga 8 - 10 menit.

Saran dari penelitian ini Lebih baik digunakan tepung lembaga jagung bebas lemak sebagai tepung substitusi pada pembuatan tiwul instan. Konsentrat protein kedelai yang relatif mahal dapat diganti dengan penggunaan bubuk susu bebas lemak (skimmed milk). Vanillin agak kurang mampu menutup cita rasa yang tidak dikehendaki pada tiwul instan dapat diganti dengan flavor-enhancer yang lebih tepat, nisalnya mocca, caramel. atau kayu manis.

\section{UCAPAN TERIMAKASIH}

Peneliti menyampaikan penghargaan yang tinggi dan terimakasih kepada Direktorat Jenderal Pendidikan Tinggi Kementerian Pendidikan dan Kebudayaan yang telah membiayai penelitian ini melalui program Riset Unggulan Tahun 2012.

\section{DAFTAR PUSTAKA}

Badrie N and Mellowes WA. 1992. Soybean Flour/oil and wheat Bran Effects on Characteristics of Cassava (Manihot esculenta cramtri) Flour Extrudate. $J$. Food Sci. 57(1): 108-111.

BeMiller JN and Whistler RL. 1996. Carbohydrates. In O.R. Fennema (Ed), Food Chemistry. Third Edition. Marcel Dekker, Inc., New York.

Blessin CW, Inglett GE, Garcia WJ and Deatherage WL. 1972. Defatted germ flour-food ingredient from corn. Food Product Development (Reprinted).

Fennema. 1996. Food Chemistry. 3th Edition. New York: Marcel Dekker, Inc. Fernando ER. 2008

Gardner HW and Inglett GE,. 1971. Food product from corn germ : Enzyme activity and oil stability. J. Food Sci. 36 : 645-648.

Glicksman M. 1986. Hydrocolloid Functionality in Fabricated Foods. Food Technology in Australia. 38: 17-25.

Grace MR 1977. Cassava Processing. Food and Agriculture Organization Plant production and protection Series No.3, Rome. 
Lindsay RC. 1996. Food Additives, in Fenmina $O$. $R$ (eds.), Food Chemistry. Third Ed. Marcel Dekker, Inc., New York.

Nielsen HC. Wall JS, Mueller JK, Warner K, and Inglett GE. 1977. Effect of Bound Lipid on Flavor of Protein Isolate from Corn germ. 54 (3): 50-510.

Nielsen HC, Wall JS, Inglett GE. 1979. Flour Containing Protein and Fiber Made from Wet-millcorn germ with Potential Food Use. Cereal Chem. 56 (3): 144146.

Soekarto ST. 1985. Penilaian Organoleptik untuk Industri pangan. Bina Ilmu, Surabaya.

Sudarmadji S, 1984. Prosedur Analisa Untuk Bahan Makanan dan Pertanian. Edisi Ketiga. Yogyakarta: Liberty
Suhendro EL, McDonough CM, Rooney LW, Waniska RD, Getneberk S. 1998. Effect of Processing Condition and Serghum Cultivar on Alkaline-Processed Snacks. Cereal Chem. 75 (2): 187-193.

Theerakulkait C, Barrett DM, Daniel MR Mc. 1995. Sweet Corn germ Enzymes Affect Odor Formation. J. Food Sci. 60 (5): 1034-1040.

Whistler JN, Bemiller JN, Paschal EF. 1984. Starck, Chemistry and Teknology. Second Edition. Academic Pers, Inc., London.

Widodo. 2004. Penampilan Agronomik Enam Genotip gandum. Skripsi. Fakultas Pertanian UNSOED, Purwokerto. Tidak Dipublikasi.

Winarno FG. 1997. Kimia Pangan dan Gizi. PT Gramedia Pustaka Utama, Jakarta. 253 hal 